\title{
Consumer Behaviour against the Changeability of the Environment
}

\author{
Ewa Mazur-Wierzbicka \\ Department of Human Capital Management, University of Szczecin' Poland
}

\begin{abstract}
The purpose of this paper is to identify the behaviours of contemporary consumer determined by ongoing social and technological changes. The layout of the paper is dictated by the implementation of the objective. The first part introduces the subject matter of consumer behaviour. Part two focuses on the issue of social changes as contribution to the creation of new trends in consumer behaviour, whereas part three focuses on the issues of technological changes as contribution to the creation of new trends in consumer behaviour. The paper has a theoretical character. It is based on a critical literature review.

Consumer behaviour is determined by a number of factors dependent of the consumer himself as well as his surroundings. Globalization of economies as well as social and technological changes have a particular impact on consumer behaviour in the 20th century. Among social changes, three main trends can be identified: customization of consumption, fragmentation and paradoxical juxtaposition of opposites. Among the changes of a technical nature surreality of means of simulation and communication stands first. Realisation of values and complexity also play an important role. All changes occurring in the social and technological areas lead to the creation of new trends in consumer behaviour. Main new trends include: increase in consumption and its changing structure, ecologization of consumption, virtualisation, socially responsible and sustainable consumption, collaborative consumption, smart shopping and other (e.g. ethnocentrism, hyperconsumption, democratization of luxury, digital abstinence, trysumer).
\end{abstract}

Keywords: consumer, trends, consumer behaviour

\section{Introduction}

Enterprises functioning in the conditions of market economy are forced to observe constantly the changes occurring in their environment and to adapt their own activity to the conditions around them. Consumers are the most important entity on the market on the demand side. Understanding consumer activities and behaviours allows a given enterprise to tailor its offer to their needs and preferences more effectively than its competition.

In times when change is a permanent element of the functioning of economic entities it is very important to observe, pay attention to changes occurring in the areas and factors determining consumer behaviour. These activities allow one to notice the changes occurring in the 
behaviours of individual groups of consumers quickly, to identify consumption trends and to predict changes in recipients' decisions.

In view of the above, the purpose of this paper is to identify behaviours of the contemporary consumer determined by the occurring sociological and technological changes. The paper has a theoretical character. It is based on a critical literature review. It is an introduction to pilot studies currently being prepared in terms of the impact of social and technological changes on the behaviour of the contemporary consumer.

\section{Consumer behaviour - introduction to the subject matter}

One of the fundamental roles played by a man, apart from the role of a citizen and maker, is the role of a consumer. The notion of a consumer is used in different contexts and has not been defined unambiguously. In the economic theory, the term "consumer" occurs as a symbolic notion representing entities that create demand and serving to present the theory of choice (Kieżel (ed.), 2000; Yeoman, 2011).

A slightly different approach to the notion of "consumer" is presented by disciplines related to broadly understood marketing issues. This difference has its source in the modern marketing concept in which it is the consumer who is the starting point for undertaken marketing measures. Examining consumer needs, desires and wishes becomes in this case the most important element of producers' and sellers' strategies.

In the case of a consumer, it is key to address his behaviours, which is of interest to a number of disciplines, in particular economy, sociology, psychology, anthropology and management. These fields address various aspects of the purchasing process and consumption of goods and services.

The literature lacks one single definition of the term "consumer behaviour". One can assume that this is " $(. .$.$) the processes involved when individuals or groups select, purchase, use or$ dispose of products, services, ideas or experiences to satisfy needs and desires" (Solomon et al., 2013, p. 5). In turn, according to other researchers, consumer behaviour includes psychological and physical activities, together with their motives and causes, carried out by persons or groups in the cycle of consumption and implementation of their goals and values, as a result of achieving satisfaction and prosperity, taking into account individual and social effects of these behaviours (Antonides \& van Raaij, 2003). There are also approaches to the term "consumer behaviour" which emphasize the role of external conditions of consumer functioning on the market and in the consumption phase for example: consumption behaviour means a coherent whole of measures, activities or steps related to making choices in the process of satisfying consumption needs in specified social, cultural and economic conditions. Consumer behaviours mean steps related to the consumption process, which is composed of a market (purchasing) behaviour and behaviour during the phase of consumption of the purchased product (Kieżel (ed.), 2010). 
It is worth noting that consumer behaviours are influenced by their attitudes which are shaped by their own experiences or by opinions created by the environment, including contemporary media. Consumer attitudes mean relatively permanent likelihood of positive or negative position towards the object of the attitude, which may involve a specific or abstract thing, people or events. Attitudes may also be created on the basis of emotions and convictions which in turn are an object of experiences with the object of the attitude (Stasiuk \& Maison, 2014). Therefore, attitudes involve an evaluation of something or somebody, while consumer behaviour means the way he acts in all phases of satisfying physiological and psychological (emotional) needs.

Consumption and consumer behaviour are determined by a number of factors dependent of the consumer himself as well as his external environment (Grzega \& Kieżel, 2017). The literature features many classifications thereof. One can identify e.g. a classification into internal determinants (i.a. disposable income, professional activity, property and savings, current level and structure of consumption) and external determinants, or a broader one which classifies consumer behaviour determinants into three equal groups: economic (i.a. income, supply, prices, marketing information, free time), social-demographic (social i.a.: social groups and reference groups, family, opinion leaders, culture and subculture; demographic i.a. (cf.: Walsh \& Mitchell, 2005) age, sex, (Rahman, 2012) household size, consumer's marital status) and psychological (i.a. attitudes, personality, perception and emotions), let alone the supreme role of macroeconomic determinants (Kieżel (ed.), 2000).

It needs to be emphasized that globalization of economies, social and technological changes (expansion of the use of information and communication technologies) have a specific impact on consumer behaviour in the 21st century. The consumption itself is also subject to globalization processes, which is related to the homogeneity of needs of purchasers and in consequence to mainstreaming consumption models which spread on a pan-national scale and create a global consumption culture (Bywalec, 2010).

\section{Social changes as contribution to the emergence of new trends in consumer behaviour}

The issue of social changes is examined mainly in sociology. Most generally, a social change is defined as a difference between the status of a social system at a specified time and the status of the same system at a different point in time (Sztompka, 2002). It features a broad scope and refers to transformations of institutions, norms, culture and social structure, thus everything that matters for social life and development. Three main trends can be identified among the changes of social nature:

- customization of consumption,

- fragmentation,

- paradoxical juxtaposition of opposites.

Customization of consumption is the main trend of the current changes. At the moment, households are made up of increasingly fewer members while there is an increase in the 
number of single-person households. Numerous consumption goods, such as the radio, the telephone or the car, have become individual goods while a few decades ago they were e.g. family goods.

The observable social changes are to a large extent associated with demographic changes around the world. The practice of taking up employment by women outside of the house is developing and fathers get involved in the life of the family in a broader scope. Spouses plan and impellent tasks jointly, they spend their leisure time together. The type of a partnership marriage is appearing more and more often and is getting stronger (Kwak, 2005). A trend among young people to enter into partnership relationships, not marital ones is also noticeable. It is also observable that not only fewer people get married, but the average age of people entering into marriage is increasingly higher - the phenomenon of "postponing marriage"1, occurs, the same trend of "putting off" applies to women having their first child ${ }^{2}$.

The above changes lead to i.a. customization of consumption demonstrated in independence and individual preferences while consumers strive to be seen as autonomous persons. This direction of changes is proof that expressing oneself is gaining importance for consumers, which is evidenced among others by the more and more popular personalization of products. One of its aspects involves e.g. acquiring and possessing luxury and unique products (JanośKresło \& Mróz, 2006). A contemporary consumer also feels like participating in taking decisions on the product's features before its final production. For this reasons, interior designers, car manufacturers and clothing companies contact consumers in order to take into consideration their private preferences for an individual product. Having higher incomes, consumers have the need to stand out on the market. This customization also steps into the sphere of services, for example before choosing a face cream, a cosmetologist will examine the customer's skin.

An individualistic attitude is a privilege today, not an obligation. People lead independent lives, create their identity, and take decisions on norms and values. Observable and progressing psychologization of life has a great impact on customization (Szlendak, 2008).

Another change in the social nature involves fragmentation. This term has a number of meanings. Fragmentation is expressed among others in market sentimentalization (consumers live the current state of soul, they live the moment) and isolated experiences. Consumers as members of their households, encouraged by numerous promotional messages, play various roles, at the same time concealing their own "self", depending on what products they are using at that given moment. They are, according to a marketing concept of a specific product, creative managers, caring mothers, resourceful hostesses.

\footnotetext{
1 For example, in the USA in a single generation, the median age of first marriage has risen from 26 to 28.5 years (Lobaugh et al., 2019).

${ }^{2}$ For example, in the USA: an increase of an average age of a woman having her first child - from 21 in 1972 to 26 in 2016 (Lobaugh et al., 2019).
} 
Segment-based production, that is the so-called Kotler's "mass customization" is also an expression of fragmentation. A decision on buying a certain good is often made before it is produced. This process is particularly seen on the furniture market or primary car market.

Mass media are also accommodated in the discussed trend. Specialist magazines and specialized TV channels are developing on the market the aim of which is to provide exciting stimulation. Brutal murders intertwine with adverts for sweets and an erotism-rich programme is followed by religious ones. A presenter dressed in a sports t-shirt and a tuxedo at the same time does not raise eyebrows anymore.

The last example concerns another change of a social nature, namely paradoxical juxtaposition of opposites. There are no role models or a single permissible style. Quite the opposite, pluralism and tolerance to all styles are present. A shift forms few styles to numerous genres is observable. New matches and juxtaposition of opposites create new forms (Mruk, 2007).

Apart from the said main trends of changes of social nature, one needs to point out to a few additional elements which also affect the creation of new trends in consumer behaviour.

For example, it needs to be noted that the contemporary man suffers from a permanent shortage of time, and his life often involves pursuit of money. In mature societies consumers more and more often flag up problems with free time which result from work overload. This situation is associated with the increase in the demand for time-saving products and services such as dishwashers, ironing washing machines as well as ready-made meals, etc. As a consequence, a new trend called personal outsourcing has emerged. It is expressed in an attempt to save time through the purchase of products and using services which guarantee it. It contributes to an increase in the demand for nanny services and services of domestic workers.

The permanent shortage of time entails negative consequences - it has an impact on i.a. the decline of values and of contact with loved ones as well as on simplifying everyday life through e.g. eating out, buying ready-made meals, using advanced technologies or shopping in shopping centres (Szlendak, 2008). Therefore, it can be concluded that consumers are interested in products that may be conveniently used and easily purchased.

Another observable change occurs in terms of caring for one's health. An increase in wealth as well as knowledge and awareness of societies contributed to changes in terms of health. In this framework consumers take up various activities aiming to improve their quality of life. More and more people use goods and services contributing to caring for one's looks and health. More and more households get different types of sporting gear, home-use medical devices or spa packages. This interest is accompanied by buying the so-called safe food and non-food products or eco products, by a change in eating habits or by employing professional principles of healthy eating. Interest in a healthy lifestyle is growing which is confirmed by observable evidence - a lot of people do sports, use food supplements, take up stress-reducing 
activities, and care for their looks and wellbeing. One can find a broad offer of many producers on the market who use natural ingredients. Advertisements and names of products feature such terms as: "bio", "fit", "natural" or "healthy".

Popularity of food products coming from different sides of the world is constantly growing. The search for new taste sensations for consumers also means an interest in new forms of food services - they are associated with celebrating most important life events. Particular attention is drawn at the moment to companies specialising in organising wedding parties. Restaurants compete in innovative ideas for creating value for the customer. They offer original menu items, surprising locations and arrangements.

When analysing changes occurring in social behaviour the impact of the economic downturn also needs to be mentioned. Changes in behaviour refer here mainly to money-spending tendencies, ways for taking decisions on purchases, and the types and quantities of purchased products. During the economic downturn consumers are mainly focused on shopping in smaller quantities or on decreasing purchase costs (Zalega, 2013). We may then deal with the so-called phenomenon of smart shopping. In a situation of demand limitation in the period of economic recession consumers protected their achieved level of consumption adjusting shopping habits to the new situation (Sobczyk, 2013) ${ }^{3}$. Smart shopping activities include rational planning of the household budget by buying necessary products at a low price ("expect more, pay less"). Meeting household needs occurs as a result of increasing shopping in discount stores, purchasing store brands, searching for information from various sources about cheaper products and special offers, buying products online, more careful preparation to shopping and avoiding compulsive shopping.

To sum up, one may refer to the findings of Euromonitor International, where it was concluded that at the social level we are dealing with changes concerning four main questions (Euromonitor). Firstly, it involves an aging society - in highly developed countries the number of people aged 65 and above is going up, which involves the increase in demand for care and medical services and there is demand for products and services relevant to persons at this age. The second question involves the phenomenon of the rich getting richer - the income of well-off persons grows, and so do disproportions between them and poor persons. The rich getting richer contributes to an intensified feeling of threat and to a rise in the demand for products and services enhancing security. Migration - movement of people between countries permanently or temporarily - was named as the third issue (Sztompka, 2005). Migration often causes a change in consumer needs or consumer choices. The fourth issue involves cocooning - also called home-focused nature of consumption. This trend involves transferring consumption form public places to one's own home (Hines, 2009). Home is becoming a place for satisfying educational or recreational needs. The cause of home-focused consumption involves on the one hand being tired of constant changes and the need to be active, and better

\footnotetext{
${ }^{3}$ The smart shopping phenomenon may result not only from household functioning in the conditions of a crisis, but it may also be associated among certain groups of consumers with rationalization of consumption.
} 
equipment of homes which allows for spending time in an interesting way. This trend is demonstrated in reinforcing the need for products that make the time spent at home nicer.

\section{Technological changes as contribution to the emergence of new trends in consumer behaviour}

The turn of the 20th and 21st century was the time of intense development of new technologies which have significantly influenced the change in the functioning of economic entities, which also applies to consumers.

The changes of a technical nature include in the first place surreality of means of stimulation and communication (Mruk, 2007). A consumer can, by means of media and technical tools, create his own world and play a role in it specified by him. Examples of such situations include creating a virtual community (computer games, thematic portals or fora where the participant can be whoever he wants) or cyber space (generally available flight simulators, PlayStation games, multidimensional film shows in the cinemas).

Other changes of a technical nature include also the so-called realisation of values (Euromonitor). In post-modernist times consumption is more important than production. People define their identity through what they buy and what they use and not like earlier by what they are or what profession they have. A post-modernist man is what he buys and what he can operate.

It is also not difficult to notice now the occurrence of the phenomenon of reversing production and consumption caused by another change of a technical nature - complexity (Mruk, 2007). The consumer is able to understand the significance and values that products entail only when he starts using them. This results in the pursuit to "handle" things becoming one of the most important objectives of a contemporary consumer (Zalega, 2013). It seems that products increasingly set conditions and ways of consumption (Mruk, 2007). A consumer must act according to product instructions in order to avoid trouble and to achieve a benefit. Creating additional benefits also leads to consumers' ever greater dependence on producers because without specific instructions and in certain cases even training they cannot fully use and enjoy the purchased products. Because of that, very often buyers are not able to use all functions of high-tech products since they do not have the relevant skills.

Thus, interest in services performing supplementary functions, that is those that enhance usability of products, grows. It needs to be emphasized that using the achievements of newest technology blurs the differences between fiction and reality as it allows living the experiences in a simulated reality. Virtual reality is universally available, which gives a possibility to create one's own world and one's own role in this world. Technology-saturated products on the one hand make it easier to satisfy needs and on the other expand their scope stimulating demand for new services related to the use of equipment. 
A significant role must be attributed here to the development of the Internet. It is a modern and fastest developing medium, which provides an attractive environment for various social groups. Its virtues which include i.a. (cf. B. Świecka, 2008): interactivity, global reach (without territorial or time restrictions), speed of communication, saving time, flexibility of action, low cost, large capacity of provided information or universality - mass nature bring benefits to all its users (Bajdak, 2003). More and more enterprises around the world have recognized the Internet as a very cost-effective tool for finding new clients, obtaining products, research, sale and information supporting business activity (Smoleń, 1996). Consumers also use the Internet more and more i.a. to shop, to obtain information about products and services (also to look for opinions on them) and to compare products and services in terms of their price as well as quality (Kułyk \& Michałowska, 2016). Among the advantages of online shopping consumers name saving time, lower prices, choice, easy access to information about products, possibility to do shopping day or night, diversified range of products, access to unique goods or numerous special offers. One also needs to note that some consumers fear shopping in this way or are reluctant to do so. This is determined mainly by the fear of receiving a good that is different to the one ordered, the lack of possibility to inspect and evaluate the product before purchasing it, high delivery costs at a low value of the purchase. Certainly, the trend of visualisation of consumption or e-consumption is strengthened thanks to the widespread use of mobile devices and benefits of using them.

The functioning of an electronic economy is the result of the development and widespread use of technology, including a rapid development of global networks. It is also defined as a digital economy, cyber-economy, e-economy or new economy that is a new paradigm of business. It is a virtual arena in which activity is carried out, transactions are performed and values are created and exchanged. Currently it is a phenomenon with a growing economic significance that changes the essence of carrying out economic activity.

E-commerce, which is defined in various ways in the literature, is a demonstration of electronic economy. It can be understood as using internet websites and electronic mail to conclude contracts (Stosio, 2002) or as transactions done by means of electronic communications, especially the Internet (Kocot, 2004). It is worth stressing that initially ecommerce served to facilitate transactions concluded by electronic means and tools, and only with the advancement of the Internet its mass scale development occurred. The development of e-commerce contributed to the advancement of electronic means of payment (i.a. virtual payment cards, prepaid cards, instant transfers, electronic money).

The development of information and communication technology has also contributed significantly to the widespread occurrence of the so-called collaborative consumption, the socalled sharing economy (that is a consumption model based on free and paid sharing, reselling, exchanging and lending goods and services, which is a new trend in consumer behaviour (Mróz, 2013), as it makes it easier to connect the supply of and demand for "available" goods and services. The increasingly popular consumers' access to the Internet or social portals and having modern mobile devices to access online payment systems allows for initiatives undertaken as part of collaborative consumption. 
In the context of shaping new trends in consumer behaviour one can then assume that as part of the observable expansive development of technology three factors play the greatest role. The first of them involves the widespread presence of the Internet, which makes it possible to access information and all types of entertainment without the need to leave the house. Today thanks to the Internet one can watch the latest movies, read a book or press. Its strength is built up along with its reach. This leads to changes in the manner of manufacturing and distributing products, changes in communicating with buyers, demand for new services and at the same time an increase in threats related to cyber space. The second factor involves the socalled media on demand, which contribute to changes in modes of distribution of offered products.

The third factor includes mobile technologies, which made mobile phones become small telecommunication centres, since apart from the calling functions they also have features such as: taking photos, browsing the web, listening to the radio, making small payments or sat nav. Next to mobile phones, smartphones and tablets also enjoy popularity. Mobile technologies contribute to easier access to information, to changes in communicating with buyers as well as to demand for new services. Modern communication technology ensures continuous flow of information throughout the world (Euromonitor).

\section{Conclusion}

Dynamic structural changes occurring in the environment create new challenges that the entrepreneurs find more and more difficult to face. Changes in consumer behaviour are the strongest factor affecting the way contemporary enterprises operate. A true challenge for enterprises is to realise the emergence of new trends in consumer behaviour, to understand them and use as inspiration for their development in the future (see more: Shaw, 2009).

New trends in consumer behaviour are a certain response to challenges coming from the environment and at the same time a way to adjust to new circumstances. There are seven main global trends. These include the aging societies, the rich getting richer, migrations, cocooning, media on demand, widespread Internet and mobile technologies. The first four trends concern social changes while the last three technological ones. 


\section{References}

[1] Antonides, G. and Raaij, W.F. van (2003)., Zachowania konsumenta. Podręcznik akademicki, Warszawa: PWN.

[2] Bajdak, A. (2003). Internet w marketingu, Warszawa: PWE.

[3] Bywalec, C. (2010). Konsumpcja a rozwój gospodarczy $i$ społeczny, Warszawa: C.H. Beck.

[4] Euromonitor, Forty Key Trend for the Next Decade: 20 Key global and consumer trends 2005-2015.

[5] Grzega, U., Kieżel, E. (2017). Trendy w zachowaniach konsumentów. In. M. BartosikPurgat (Ed.), Zachowania konsumentów. Globalizacja, nowe technologie, aktualne trendy, otoczenie społeczno-kulturowe, Warszawa: PWN.

[6] Hines, A. (2009). "Consumer trends in three different worlds", The Futurist, July-August.

[7] Janoś-Kresło, M. and Mróz B. (2006). Konsument $i$ konsumpcja we współczesnej gospodarce, Warszawa: Wyd. SGH.

[8] Kieżel, E. (Ed.) (2000). Rynkowe zachowania konsumentów, Katowice: AE w Katowicach.

[9] Kieżel, E. (Ed.) (2010). Konsument i jego zachowania na rynku europejskim, Warszawa: PWE.

[10] Kocot, W. (2004), Wpływ Internetu na prawo umów, Warszawa: LexisNexis.

[11] Kułyk, P. and Michałowska, M. (2016). "Consumer behaviour on the e-commerce market in the light of empirical research in Lubuskie voivodeship", Management, vol. 20, no. 1 , pp. $239-255$.

[12] Kwak, A. (2005). Rodzina $w$ dobie przemian. Matżeństwo i kohabitacja, Warszawa: Żak. Lobaugh, K., Stephens M. B. and Simpson, J. (2019). The consumer is changing, but perhaps not how you think, Deloit.

[13] Mróz, B. (2013). Konsument w globalnej gospodarce. Trzy perspektywy, Warszawa: Oficyna Wydawnicza SGH.

[14] Mruk, H. (2007). Makrotrendy a zachowania konsumentów. In Z. Kędzior (Ed.), Konsument - Gospodarstwo domowe - Rynek, Katowice: AE w Katowicach.

[15] Rahman, M. S. (2012). 'Dynamics of consumers' perception, demographic characteristics and consumers' behavior towards selection of a restaurant: an exploratory study on Dhaka city consumers", Business Strategy Series; Northampton, vol. 13, no 2, pp.75-88.

[16] Shaw, F. (2009), "Uncertainty and the new consumer", Foresight, vol. 4, pp. 4-13.

[17] Smoleń, T. (1996). „Marketing na stronach WWW”, Marketing w Praktyce, no 12, p. 5.

[18] Solomon, M.R, Bamossy, G.J., Askegaard, S.T. and Hogg, M.K. (2013). Consumer behavior- a European perspective, 5th edn. Harlow: Pearson Education.

[19] Stasiuk, K. and Maison, D. (2014). Psychologia konsumenta, Warszawa: PWN.

[20] Stosio, A. (2002). Umowy zawierane przez Internet, Warszawa: Dom Wydaw. ABC.

[21] Szlendak, T. (2008). Socjologia rodziny, Warszawa: PWN.

[22] Sztompka, P. (2002). Socjologia. Analiza społeczeństwa, Kraków: Znak.

[23] Sztompka, P. (2005). Socjologia zmian społecznych, Kraków: Znak.

[24] Świecka, B. (2008). Detaliczna bankowość elektroniczna, Warszawa: CeDeWu. 
[25] Walsh, G. and Mitchell, V.W. (2005), "Demographic characteristics of consumers who find it difficult to decide', Marketing Intelligence \& Planning, vol. 23, no. 3, pp. 281-95.

[26] Yeoman, I. (2011). "Modeling consumer behavior", Journal of Revenue and Pricing Management; vol. 10, no. 5, pp. 399-400.

[27] Zalega T. (2013). „Nowe trendy w zachowaniach konsumpcyjnych miejskich gospodarstw domowych w okresie kryzysu”, Marketing i rynek, no 8, pp. 24-31. 